\title{
Correction to: Edrioasteroidea from the Seifen Formation of the Westerwald, Rhenish Slate Mountains (Lower Devonian, Germany), part 2: Sumrallia rseiberti gen. et sp. nov.
}

\author{
Peter Müller ${ }^{1}$ - Gerhard Hahn ${ }^{2}$
}

Published online: 6 November 2017

(C) Paläontologische Gesellschaft 2017

\section{Correction to: PalZ \\ DOI 10.1007/s12542-017-0356-6}

In Müller and Hahn the Email address of the first author contained printing errors. The correct Email address is

$\checkmark$ Peter Müller

mueller-lgh@t-online.de

Furthermore, also the captions of Figure 2 and 3 contained printing errors. The correct Figure captions are reproduced in full below. We apologize for these errors.

Fig. 2 Sumrallia rseiberti gen. et sp. nov., Seifen III, Seifen Formation. a PWL 2015/5973-LS, the smallest known specimen surely belonging to the taxon; diameter $=4.4 \mathrm{~mm}$. b PWL 2015/5976 ${ }^{1}$ LS, a juvenile specimen with very well preserved oral region, found on the external surface of a valve of a strophomenid brachiopod; diameter $=8.5 \mathrm{~mm}$. c PWL 2015/5976 ${ }^{2}$-LS, juvenile specimen encrusted by a bryozoan colony; diameter $8.5 \mathrm{~mm}$. d PWL 2015/5975 ${ }^{1}$-LS,. A complete juvenile sspecimen with somewhat raised oral region; diameter $7.8 \mathrm{~mm}$. Associated with Pyrgocystis? postpetalus Müller and Hahn, 2010 (PWL 2015/59732-LS). All specimens were found on the external surface of a valve of a strophomenid brachiopod. e PWL 2015/5978-LS, a nearly complete, well preserved specimen, found on the internal surface of a valve of a strophomenid brachiopod; diameter $=11.3 \mathrm{~mm}$. f PWL 2015/5977-LS, a very well preserved specimen, associated with an auloporid coral; maximum diameter $=9.9 \mathrm{~mm}$. g PWL 2015/5977-LS, detailed photograph of oral region (compare Fig. 2f); width of picture about $3 \mathrm{~mm}$. h PWL 2015/5981-LS, detailed photograph of oral region (compare Fig. 4a); width of picture about $4 \mathrm{~mm}$.

Fig. 3 Sumrallia rseiberti gen. et sp. nov., Seifen III, Seifen Formation. a Reconstruction of Sumrallia rseiberti gen. et sp. nov. A, B, $\mathrm{C}, \mathrm{D}$ and $\mathrm{E}=$ ambulacra, $\mathrm{AB}, \mathrm{BC}, \mathrm{CD}, \mathrm{DE}$ and $\mathrm{EA}=$ interambulacra, gray zones $=$ peripheral rim, light grey $=$ proximal circle of the peripheral rim. b Reconstruction of the oral region. PO (primary oral plates) and LBP (lateral bifurcations plates) are primary peristomial cover plates, $\mathrm{C}=$ shared cover plates, $\mathrm{H}=$ hydropore oral plate, $1=$ primary ambulacral cover plates (type 1 ), 2 = secondary ambulacral cover plates (type 2 ); scale $=1 \mathrm{~mm}$.

The online version of the original article can be found under doi:10.1007/s12542-017-0356-6.

Peter Müller

mueller-lgh@t-online.de

Gerhard Hahn

gumbo1@gmx.net

1 Am Grauen Stein 4, 56244 Freilingen, Germany

2 Berliner Straße 31, 35282 Rauschenberg, Germany 